University of Nebraska - Lincoln

DigitalCommons@University of Nebraska - Lincoln

USDA National Wildlife Research Center - Staff Publications
U.S. Department of Agriculture: Animal and Plant Health Inspection Service

June 2001

\title{
Territorial defense by coyotes (Canis latrans) in Yellowstone National Park, Wyoming: who, how, where, when, and why
}

Eric M. Gese

Utah State University, eric.gese@usu.edu

Follow this and additional works at: https://digitalcommons.unl.edu/icwdm_usdanwrc

Part of the Environmental Sciences Commons

Gese, Eric M., "Territorial defense by coyotes (Canis latrans) in Yellowstone National Park, Wyoming: who, how, where, when, and why" (2001). USDA National Wildlife Research Center - Staff Publications. 530. https://digitalcommons.unl.edu/icwdm_usdanwrc/530

This Article is brought to you for free and open access by the U.S. Department of Agriculture: Animal and Plant Health Inspection Service at DigitalCommons@University of Nebraska - Lincoln. It has been accepted for inclusion in USDA National Wildlife Research Center - Staff Publications by an authorized administrator of DigitalCommons@University of Nebraska - Lincoln. 


\title{
Territorial defense by coyotes (Canis latrans) in Yellowstone National Park, Wyoming: who, how, where, when, and why
}

\author{
Eric M. Gese
}

\begin{abstract}
Territorial defense and maintenance are an important facet of the social ecology of most carnivore species. From January 1991 to June 1993, we observed 54 coyotes (Canis latrans) for 2507 h in Yellowstone National Park, Wyoming, during which we observed 112 instances of territory defense. The identity of the coyotes involved in challenging and evicting intruding animals was known. Alpha coyotes were most likely to be involved in territorial evictions of intruding animals, followed by beta individuals; pups participated little in territory defense. Coyotes evicting intruders generally had a numerical advantage when challenging the intruders. Territory-defense rates were highest during and immediately after the breeding season and during the time of pup emergence from the den. All chases of intruders ended at the boundary of the resident coyote pack's territory. Physical contact between the intruding animal and resident pack members occurred with no intruders being killed or seriously injured. Physical contact consisted of fighting and ritualized behaviors, with only a few instances in which fighting led to blood being drawn or minor injuries to the intruder. Most encounters resulted in a hasty retreat from the area by the intruder(s). While indirect means of territory maintenance (i.e., howling and scent-marking) were utilized by resident packs, trespassing still occurred and direct confrontation was needed to enforce boundaries and assert occupancy against other resident packs, as well as against lone intruders seeking territory vacancies. Territoriality was advantageous in that territory holders generally had higher survival rates (except pups), contributed all the reproductive effort to the population, and had greater access to food resources. In contrast, nonterritorial animals had lower survival rates, did not breed, and had reduced access to food (ungulate carcasses) during winter.
\end{abstract}

Résumé : La défense et la conservation du territoire constituent une facette importante de l'écologie sociale de la plupart des espèces de carnivores. De janvier 1991 à juin 1993, nous avons observé 54 coyotes (Canis latrans) pendant 2507 h dans le parc national de Yellowstone, au Wyoming, au cours desquelles nous avons étudié 112 cas de défense de territoire. Les coyotes qui ont défié et chassé des intrus de leur territoire ont été identifiés. Les coyotes alpha sont plus enclins à évincer les intrus de leur territoire, suivis des coyotes bêta; les petits participent peu à la défense territoriale. Les coyotes qui évincent des intrus ont généralement l'avantage numérique lorsqu'ils les poursuivent. La fréquence des cas de défense territoriale est maximale pendant et immédiatement après la saison de reproduction et au moment de la sortie des petits des terriers. Toutes les poursuites observées ont pris fin à la frontière du territoire de la meute résidante. Les contacts physiques entre intrus et résidants de la meute n'ont jamais abouti à la mort d'un intrus, ni même à des blessures graves. Les contacts physiques se limitent à des batailles ou à des comportements rituels et seulement quelques batailles se sont terminées par un épanchement de sang ou par l'administration de blessures légères à l'intrus. La plupart des rencontres se sont soldées par la fuite précipitée des intrus de la zone occupée. Malgré l'utilisation des méthodes indirectes de conservation des territoires (i.e., les hurlements et l'imprégnation d'odeurs) par les membres du troupeau résidant, les intrus ont continué de passer les frontières territoriales et la confrontation directe s'est avérée nécessaire pour faire respecter les frontières et défendre le territoire contre les coyotes d'autres meutes résidantes et contre des coyotes solitaires se cherchant un territoire libre. La territorialité est un atout, puisque les détenteurs de territoires (à l'exception des petits) ont généralement un meilleur taux de survie, ils sont les seuls individus de la population à participer à l'effort reproducteur et ils ont plus facilement accès aux ressources alimentaires. Au contraire, les coyotes non territoriaux ont des taux de survie plus faibles, ils ne se reproduisent pas et ils ont un accès limité aux ressources alimentaires (carcasses d'ongulés) en hiver.

[Traduit par la Rédaction]

\section{Introduction}

The territory of an animal has been defined as the area it will defend against individuals of the same species (Burt 1943; Mech 1970). Territoriality allows animals to exclude potential competitors from access to mates, food, space, and cover. Brown and Orians (1970) proposed that territoriality is implied if there is little overlap between home ranges, scent-marking behavior is performed, and agonistic interactions occur. Several studies have demonstrated direct and indirect

Received August 29, 2000. Accepted March 8, 2001. Published on the NRC Research Press Web site at http://cjz.nrc.ca on June 1, 2001.

E.M. Gese. National Wildlife Research Center, Department of Fisheries and Wildlife, Utah State University, Logan, UT 84322-5295, U.S.A. (email: egese@cc.usu.edu). 
mechanisms that many carnivore species use to maintain their territory boundaries, including scent-marking (Peters and Mech 1975; Camenzind 1978; Rothman and Mech 1979; Barrette and Messier 1980; Bowen and Cowan 1980; Wells and Bekoff 1981; Bailey 1993; Caro 1994; Gese and Ruff 1997), howling (Harrington and Mech 1978a, 1978b, 1979; Gese and Ruff 1998), and confronting intruders (Camenzind 1978; Bekoff and Wells 1986; Mech 1993, 1994).

Radiotelemetry locations that delineate non-overlapping home ranges between social units have been used to infer territoriality among North American canids (e.g., Mech 1973; Fritts and Mech 1981; Gese et al. 1988; Fuller 1989). Evidence of territorial behavior has been documented from reports of intraspecific strife and collection of carcasses of animals killed by conspecifics along territory borders (Van Ballenberghe and Erickson 1973; Mech 1994). However, because of the secretive nature and wide-ranging habits of most canids, direct observations of territory defense are rare and limited to a few anecdotal accounts (e.g., Mech 1966; Peterson 1977). Murie (1944) gave one of the first accounts of an encounter between a wolf (Canis lupus) pack and a strange wolf. Mech (1993) provided a detailed description of a confrontation between two wild wolves in the High Arctic of Canada involving "ritualized fighting" (Schenkel 1947; Moran et al. 1981) between the two wolves. Camenzind (1978) reported 13 territorial encounters between coyotes (Canis latrans) in the National Elk Refuge, Wyoming. Bekoff and Wells (1986) observed 55 pack-intruder encounters, but identified the resident coyotes only as adults or helpers. Common to these observations of wolves and coyotes was the role played by the dominant members of the pack in actively attacking and chasing intruders from the territory, the cessation of pursuit at the territory boundary, and scentmarking and howling bouts by the defenders following the encounter (Camenzind 1978; Mech 1993). Wolves and coyotes differ in that wolves typically kill the intruder (Mech 1994), while coyotes rarely do so (but see Okoniewski 1982).

The coyotes in Yellowstone National Park, Wyoming, have not been persecuted for several decades, allowing for observation of a free-ranging coyote population. During the collection of $2507 \mathrm{~h}$ of behavioral observations on coyotes in Yellowstone National Park (Gese et al. 1996a, 1996b, $1996 c$ ), we witnessed and documented 112 incidents of territory defense. Because we were able to watch and identify members of the resident packs (Gese et al. 1996a, 1996b, $1996 c$ ) during these encounters, we investigated the following questions: ( $i$ ) Which of the pack members provide most of the territory defense and how many are involved? (ii) What is the affiliation or social status of the intruding coyote(s)? (iii) What tactics are used to evict intruders from the territory and how long does a defense encounter last? (iv) Does territory defense occur with equal frequency across the entire territory? (v) Does territory defense change seasonally? (vi) What advantages do territory holders receive in terms of fitness (i.e., reproduction, demography, and food resources; Davies 1978) compared with nonterritorial animals, i.e., why do coyotes defend a territory?

\section{Study area and methods}

Observations of territory defense by coyotes were recorded during collection of data on coyote foraging ecology, predation, and dispersal (Gese et al. 1996a, 1996b, 1996c) in the Lamar River Valley, Yellowstone National Park $\left(44^{\circ} 52^{\prime} \mathrm{N}, 110^{\circ} 11^{\prime} \mathrm{E}\right)$. Elevation of the study area is about $2000 \mathrm{~m}$. Winters are long and cold with most of the annual precipitation falling as snow (Dirks and Martner 1982; Houston 1982). Habitats identified in the study area included forest, grassland, sage-grassland, riparian, mesic meadow, and mesic shrub-meadow (see descriptions in Gese et al. 1996a).

Coyotes were captured with padded leg-hold traps with attached tranquilizer tabs (Balser 1965). Each coyote was immobilized (Cornely 1979) for handling and processing, then sexed, ear-tagged, and radio-collared. We extracted the first vestigial premolar from the lower jaw to estimate age by analysis of cementum annuli (Linhart and Knowlton 1967). Pups were captured at the den when 10-12 weeks old and surgically implanted with an intraperitoneal transmitter. Individuals were classified as pups ( $<12$ months old), yearlings (12-24 months old), or adults (>24 months old). Coyotes were classed as members of a resident pack or as transient individuals following Bowen (1978) and Gese et al. (1988). Dispersing coyotes were identified as residents permanently leaving their established territory or animals entering the valley that were not known residents or transients (i.e., they had dispersed from elsewhere). Residents were classified into three social classes: alphas (the dominant, breeding adult male and female), betas (adults and yearlings subordinate to the alphas but dominant over pups), and pups (young of the year that were subordinate to both alphas and betas) (Schenkel 1947, 1967; Rabb et al. 1967; Mech 1970). Coyotes were classified into the next age or social class as they grew older.

Behavioral observations of radio-collared, implanted, and unmarked coyotes were made using a $15-30 \times$ spotting scope from a vehicle or observation points on hills overlooking the valley and followed the sampling procedures described in Gese et al. (1996a, $1996 b, 1996 c$ ). We used focal-animal sampling (Lehner 1979), recording behaviors continuously on a computer or on a tape recorder and transcribing later. I trained all observers for 5-7 days in order to maintain consistent interpretation and recording of behaviors (Lehner 1979; Martin and Bateson 1993). Most observations were made during daylight hours (07:00-20:00) from October to July; high grass in August and September prevented data collection. Nocturnal observations were also conducted with a nightvision scope (Litton Electron Devices, Tempe, Arizona). An encounter between two or more coyotes was classed as a territorydefense event if one or more animals chased the intruder(s) to the territory boundary or out of the territory. For each encounter we recorded the identity of the animals involved, the duration of the encounter or chase, and the number of coyotes involved in the encounter. Instances of agonistic behavior between animals that involved scavenging at a carcass were not considered territory defense; similar to aggregations observed by Camenzind (1978) and Bekoff and Wells (1986). Agonistic encounters at a carcass were temporary and did not result in expulsion of the intruding individual. Whenever possible we recorded the location of each territory-defense event to the nearest $10-\mathrm{m}$ grid intersection on a $1: 24000$ U.S. Geological Survey topographic map using the Universal Transverse Mercator (UTM) grid system, or provided a verbal description of where the defense occurred using known landmarks. The territories and their associated boundaries were determined from visual locations of foraging, scent-marks, and howling (Gese and Ruff 1997, 1998) independently of the territory-defense events.

Territoriality allows animals to exclude potential competitors from access to mates, food, space, and cover. To ascertain the benefits of territoriality in terms of fitness (Davies 1978), and hence why animals defend a territory, we compared several demographic and foraging parameters between territorial (resident alphas, betas, and pups) and nonterritorial (transients and dispersers) animals. As a measure of access to mates we compared the percentages of the cohorts involved in breeding opportunities, i.e., individuals that 
either produced a litter of pups or were observed in a copulatory tie. We examined the percentage of pups surviving to 5 months of age as a measure of reproductive success (at 5 months the pups were independent of parental care and recruited into the population). We calculated annual survival rates, using MICROMORT (Heisey and Fuller 1985), for the various cohorts by extrapolating daily survival rates (Trent and Rongstad 1974) using animals of known fate. Dispersal rates were estimated similarly to survival rates but substituting dispersal for death in the calculation (Fuller 1989). From behavioral observations of foraging ecology (Gese et al. 1996a) we compared the percentages of time spent feeding on an ungulate carcass as a measure of access to food resources in winter. Because small mammals are a year-round prey item and an important alternative food source to ungulate carcasses (Gese et al. 1996a, 1996c), the rate of capture of small mammals and the percentage of predation attempts resulting in successful capture of a small mammal were estimated following the procedures described in Gese et al. (1996b). All territorial animals (alphas, betas, pups) and transients were used to estimate the previously described demographic and foraging parameters. For documentation of the dispersing cohort, territorial and transient animals that dispersed were used to calculate survival and dispersal rates. However, because these coyotes left the valley and were no longer available for behavioral observations, we used the dispersers that immigrated into the valley for determining measures of reproduction and foraging (i.e., these dispersers were under the same constraints of food, mates, and space as the other coyotes in the valley). All territorial and transient animals were recognizable and known (Gese et al. 1996c), therefore unknown individuals entering the valley had to have dispersed from elsewhere and these animals were classed as dispersers whose reproductive and foraging behavior was observed and recorded. All statistical tests followed the procedures of Sokal and Rohlf (1981) and Zar (1996).

\section{Results}

We observed a total of 54 coyotes for $2507 \mathrm{~h}$ from January 1991 to June 1993. Of the 54 coyotes, 49 were members of resident packs and 5 were transient individuals. We observed 11 coyotes of the Bison pack for $498 \mathrm{~h}, 9$ members of the Druid pack for $432 \mathrm{~h}, 11$ animals in the Fossil Forest pack for $593 \mathrm{~h}, 10$ coyotes of the Norris pack for $463 \mathrm{~h}$, and 8 members of the Soda Butte pack for $470 \mathrm{~h}$. The five transients were observed for $51 \mathrm{~h}$. Thirty-one coyotes were radio-collared or carried implanted transmitters and 23 animals were not marked but were recognized by physical characteristics. We observed 29 males and 23 females; 2 unmarked coyotes were of unknown sex. For more details on the individuals observed and pack histories see Gese et al. (1996a, $1996 b, 1996 c)$. In addition, a minimum of eight animals immigrated into or passed through the valley and were classed as dispersers; $53 \mathrm{~h}$ of observation were collected on these individuals. Three dispersers were male and two were female; three were of unknown sex.

\section{Who defended the territory and who was evicted?}

We recorded 112 instances of territory defense during our observations. These chases averaged $2.87 \mathrm{~min}$ in duration (range 0.3-26.8 min). All 112 territory-defense events observed were performed by members of resident coyote packs (Table 1). During $51 \mathrm{~h}$ of observation of transient coyotes, none was observed to pursue, attack, or chase another coyote out of an area. Of the 112 observations of territory defense, a member of the alpha pair was involved in $87 \%(N=98)$ of
Table 1. Frequency, by sex and social rank, with which resident coyotes (Canis latrans) participated in territory defense when in a group or alone, Yellowstone National Park, Wyoming, 1991-1993.

\begin{tabular}{llllll}
\hline & \multicolumn{3}{l}{ In a group } & & Alone \\
\cline { 2 - 3 } Social rank & Females & Males & & Females & Males \\
\hline Alpha & 66 & 86 & & 7 & 25 \\
Beta & 15 & 51 & & 0 & 12 \\
Pup & 6 & 3 & & 0 & 0 \\
\hline
\end{tabular}

those chases; alpha males and females participated in $77 \%$ $(N=86)$ and $59 \%(N=66)$ of the chases, respectively. At least one of the beta coyotes was involved in $48 \%(N=54)$ of the chases; beta males and females participated in $45 \%$ $(N=51)$ and $13 \%(N=15)$ of the territory-defense events, respectively. Pups were involved in only $7 \%(N=8)$ of the chases, with male pups and female pups participating in 3\% $(N=3)$ and $5 \%(N=6)$ of the territory-defense events, respectively. A member of the coyote pack, acting alone, attacked or pursued an intruder in 41 encounters. Alpha males and females attacked an intruder in 58\% $(N=24)$ and $17 \%$ $(N=7)$ of these solo encounters, respectively $\left(\chi^{2}=9.32\right.$, $\mathrm{df}=1, P=0.0023)$. Among the beta individuals, a highranking beta male attacked alone in $24 \%(N=10)$ of the encounters, while beta females did not attack alone $\left(\chi^{2}=\right.$ $10.00, \mathrm{df}=1, P=0.0016)$. Pups were not observed chasing an intruder by themselves.

The identity of the animals being chased out of the territory was often known. Members of a resident pack from an adjacent territory were involved in $33 \%(N=37)$ of the evictions (i.e., residents had trespassed into their neighbors' territory). Transient coyotes comprised $6 \%(N=7)$ of the chases, while unknown and unmarked coyotes (i.e., dispersers entering the valley) were evicted in $61 \%(N=68)$ of the encounters. Transients comprised $13-15 \%$ of the coyote population in the Lamar River valley annually, so the proportion evicted from a resident territory was similar. The unknown coyotes were not identified residents or transients (Gese et al. 1996a, 1996b, 1996c; Gese and Ruff 1997, 1998), thus these coyotes were likely dispersing animals in search of territory vacancies or attempting to gain acceptance into a resident pack. In 16 of the 41 solo encounters, the sex of the intruder was known. In these solo interactions, a resident male evicted an intruding male in 10 encounters, a resident female evicted a same-sex intruder in 4 cases, and a resident male chased out a female intruder in 2 encounters, but a resident female was never observed evicting an intruding male by herself $\left(\chi^{2}=8.89\right.$, df $\left.=1, P=0.0029\right)$.

The size of the group chasing the intruder(s) and the size of coyote group being chased or evicted from the territory varied. The distribution of sizes of coyote groups pursuing an intruder, or intruders, differed significantly from the distribution of sizes of groups being chased $\left(\chi^{2}=37.31, \mathrm{df}=4\right.$, $P=0.0001$; Fig. 1). The number of coyotes chasing the intruder(s) was $2.13 \pm 1.18$ (mean $\pm \mathrm{SD}$ ) coyotes/group, whereas the size of the intruding group was $1.32 \pm 0.7$ coyotes $(t=$ $-6.2023, P=0.0001)$. In $45 \%(N=50)$ of the observations, the group chasing the intruders was equal in size to the group being chased (Fig. 2). The residents had a numerical advantage over the intruders in $51 \%(N=57)$ of the evictions, while the intruders had a numerical advantage in only 
Fig. 1. Number of encounters during which coyote (Canis latrans) groups of different sizes chased an intruder(s) or were chased by residents during a territorial interaction, Yellowstone National Park, Wyoming, 1991-1993.

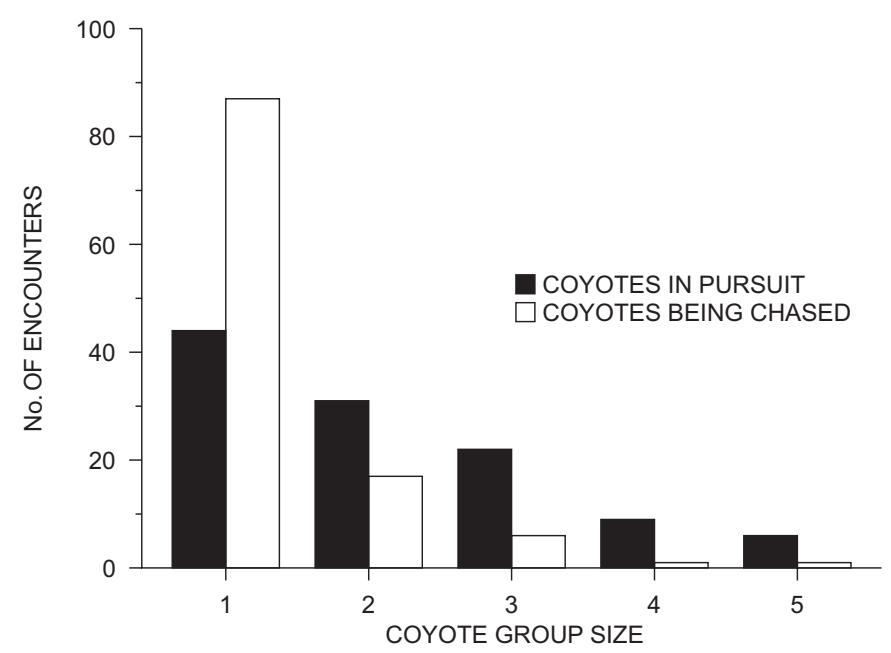

$4 \%(N=5)$ of the chases, but still retreated from the residents' territory $\left(\chi^{2}=42.66\right.$, df $\left.=2, P=0.0001\right)$.

What tactics were used to evict intruders?

Most $(N=83)$ of the evictions of intruders involved the resident(s) chasing the intruder out of the territory without any physical contact occurring between the animals. Of the 28 chases that involved the resident making actual physical contact with the intruder, alpha males, alpha females, and beta males fought with the intruder in 21,3 , and 5 chases, respectively. Beta females and pups were not observed to make contact with intruders. The resident coyote often rolled the intruder when first making contact, then bit or grappled with the intruder, at times inflicting visible wounds and causing bleeding. These fights usually lasted only 5-15 s, at which time the resident would release its hold on the intruder, then the intruder would typically withdraw from the resident animal while performing ritualized submissive postures with tail tucked, head held low, mouth gaping, and ears held flat. In 7 instances the resident coyote attacked the intruder multiple times (2-5 attacks) until the intruder crossed the territory boundary, whereupon the attacks were terminated.

\section{When did territory defense occur?}

The 112 encounters or territorial evictions over $2507 \mathrm{~h}$ of observation equates to 1 territory-defense event every $22.4 \mathrm{~h}$ of observation. Standardizing the encounters to chases per $100 \mathrm{~h}$ of observation because of varying sample sizes among the months (Fig. 3), territory defense appeared to increase as the breeding season approached (December), remained high during the breeding season (January-February), with a peak observed in March (gestation season), followed by a decline after pups had been whelped in the den (May) and another increase when pups began to emerge from the den (June). This pattern was consistent across all 3 years of observation. When the level of participation among the three social classes was examined on a monthly basis, alpha animals participated in territory defense consistently throughout the year (Fig. 4), while beta animals appeared to increase their level
Fig. 2. Distribution of the numerical advantage held by a coyote or group of coyotes when chasing an intruder(s) or being chased by residents during a territorial encounter, Yellowstone National Park, Wyoming, 1991-1993. The number 0 indicates no numerical advantage during an encounter.

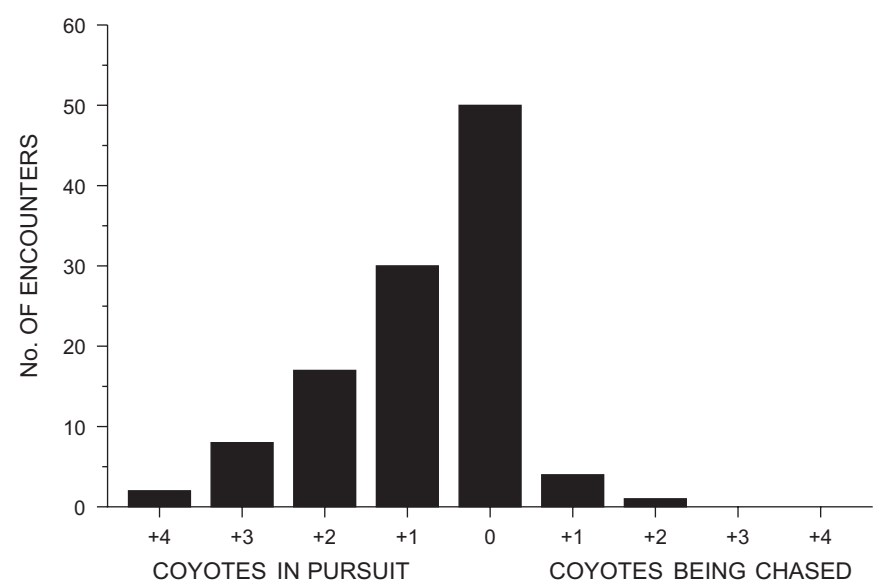

of participation as the year passed (perhaps as they grew older); pups participated only during winter.

\section{Where did territory defense occur?}

The initiation of a territory-defense event generally began within the territory and always ceased at or near the territory boundary (Fig. 5). The length of some chases often exceeded $1 \mathrm{~km}$, one chase covering $>1.5 \mathrm{~km}$ before the intruder vacated the residents' territory. In that lengthy chase the intruder was about $0.5 \mathrm{~km}$ away from the alpha male at the beginning of the chase. The alpha male closed that gap in about the first $1 \mathrm{~km}$ of the chase, rolling and fighting with the intruder all the way to the border. Once the intruder or intruders had crossed out of the resident territory, the resident animals stopped pursuit. These boundaries were often physiographic features (i.e., rivers or roads; Fig. 5), and pursuit of the intruder, particularly when it involved members of an adjacent pack, would terminate at the border, upon which both resident packs would commence to howl and bark at each other and scent-mark their side of the border.

\section{Why defend: the advantages of territoriality}

Animals that hold and defend territories should derive benefits from such behavior in terms of fitness. Davies (1978) postulated that certain parameters in terms of food and mates are assumed to influence fitness directly. To examine why animals hold a territory, we compared various demographic and foraging parameters between territory holders and nonterritorial individuals (Table 2). For access to mates and breeding opportunities, alpha individuals accounted for $94 \%$ of the breeding in the population (one alpha male was displaced prior to the breeding season); beta individuals represented $6 \%\left(\chi^{2}=35.70, \mathrm{df}=1, P=0.0001\right)$. Among the beta coyotes, one male was observed in a copulatory tie and one beta female produced a litter of pups. Resident pups, transients, and dispersers were not involved in breeding opportunities. Of the pups produced by alpha coyotes, $66 \%$ survived to 5 months of age and were recruited into the population, while none of the pups born to the beta female 
Fig. 3. Changes in the rate of territory defense by resident coyotes from October to July, Yellowstone National Park, Wyoming, 1991-1993.

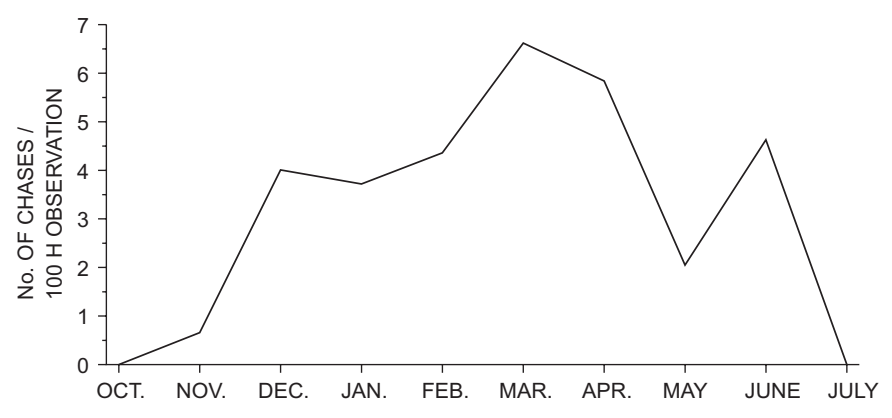

Fig. 5. Locations and directions of chases of intruders during observations of territory defense, Yellowstone National Park, Wyoming, 1991-1993. An arrow indicates the direction of the chase and the arrowhead indicates the terminus.

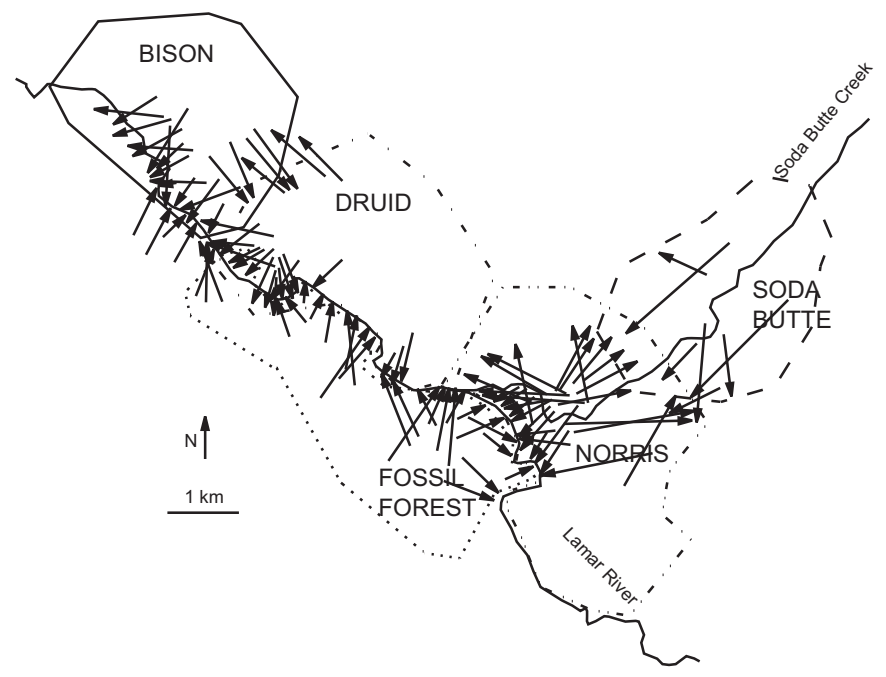

survived $\left(\chi^{2}=8.46\right.$, df $\left.=1, P=0.0036\right)$. Annual survival rates varied among the cohorts. Mean annual survival rates were highest for alphas, betas, and transients, while the lowest rates were among pups and dispersers $(F=248.92, P<$ $0.001)$. Among the alpha cohort, three alpha males died but no alpha females died during the 3 years of the study. Mean annual dispersal rates were lowest for the alpha coyotes (one alpha male was displaced and left the territory), while dispersal was more prevalent among betas, pups, and transients. With regard to access to food resources, alpha and beta coyotes had the highest access to ungulate carcasses in winter, while resident pups, transients, and dispersers had the least access $(F=9.961, P<0.001)$. Small-mammal capture rates were high for all territory holders and transients, but lowest for dispersers $(F=2.37, P=0.062)$. Percent success of capturing small mammals also varied among the cohorts $\left(\chi^{2}=\right.$ 27.97, $\mathrm{df}=4, P=0.0001$ ), with pups and dispersing individuals having lower capture success than alphas, betas, and transients.

\section{Discussion}

Territoriality among wild canids is a concept readily accepted by researchers, yet the actual mechanisms are rarely
Fig. 4. Level of participation in territory defense among the social classes from December to June, Yellowstone National Park, Wyoming, 1991-1993. Only months with >5 chases are included.

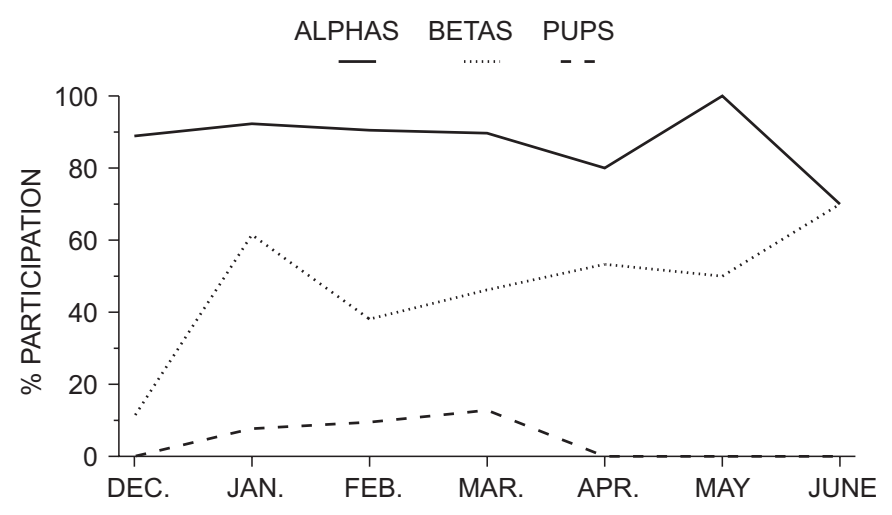

observed. Howling and scent-marking are indirect means of territory defense and maintenance and have been documented for wolves (Peters and Mech 1975; Rothman and Mech 1979; Harrington and Mech 1978a, 1978b, 1979, 1983; Harrington 1987) and coyotes (Camenzind 1978; Barrette and Messier 1980; Bowen and Cowan 1980; Gese and Ruff 1997, 1998). Observations of direct territory defense are more difficult to acquire, owing to the secretive nature of wild canids. The few researchers fortunate enough to witness actual confrontations between intruders and residents have concluded that the dominant individuals in the pack were usually the aggressors against intruding animals, and that eviction of these individual(s) generally ended at the territory boundary (Camenzind 1978; Bekoff and Wells 1986; Mech 1993, 1994). Our observations lend support to these conclusions.

We found that the alpha members of the pack were most likely to confront an intruder or trespassing pack; the alpha male, in particular, appeared to assume the role of territorial enforcer, even when alone and possibly outnumbered. The beta animals, usually high-ranking males, also actively participated in evicting intruders, but were less likely to attempt to expel an intruder by themselves. Pups generally did not participate in territory defense, and never by themselves, but if they did so it was always in the company or in support of older pack members. Bekoff and Wells (1986) observed 55 pack-intruder encounters and found that pack members "won" $75 \%$ of the interactions; at least one adult was involved in $95 \%$ of the encounters, and a helper participated in $82 \%$ of the interactions. Territorial strife among wolves similarly involves alpha animals. Mech (1993) observed an alpha male and his mate chase an alien wolf for $1.2 \mathrm{~km}$ on Ellesmere Island, Nunavut, Canada. In Minnesota, 13 (possibly 3 more) of 22 wolves killed near territory boundaries were alpha individuals (Mech 1994).

Resident animals generally held a numerical advantage during a confrontation and typically intruders hastily retreated at the approach of the resident pack. Camenzind (1978) similarly found that intruders were consistently expelled from occupied territories. Bekoff and Wells (1986) reported that the mean group size for the resident "winners" of an encounter was 2.5, while for those that lost, the mean group size averaged 1.1 coyotes. In contrast, "losing" residents averaged 1.3 coyotes per group, while "winning" intruder groups averaged 1.4 coyotes per group. Thus, numerical advantage 
Table 2. Comparison of various reproductive, demographic, and foraging parameters between territorial and nonterritorial coyotes, Yellowstone National Park, Wyoming, 1991-1993.

\begin{tabular}{|c|c|c|c|c|c|c|c|}
\hline & $\begin{array}{l}\% \text { of } \\
\text { animals } \\
\text { breeding }\end{array}$ & $\begin{array}{l}\% \text { of pups } \\
\text { surviving to } 5 \\
\text { months of age }\end{array}$ & $\begin{array}{l}\text { Annual } \\
\text { survival } \\
\text { rate }\end{array}$ & $\begin{array}{l}\text { Annual } \\
\text { dispersal } \\
\text { rate }\end{array}$ & $\begin{array}{l}\% \text { time spent } \\
\text { feeding on } \\
\text { carcass }\end{array}$ & $\begin{array}{l}\text { Small-mammal } \\
\text { capture rate } \\
\text { (no./h) }\end{array}$ & $\begin{array}{l}\text { Capture } \\
\text { success } \\
(\%)\end{array}$ \\
\hline \multicolumn{8}{|c|}{ Territorial coyotes } \\
\hline Alphas & 93.7 & 66.1 & 0.91 & 0.03 & 2.7 & 2.3 & 38.2 \\
\hline Betas & 6.2 & 0 & 0.96 & 0.14 & 3.2 & 2.5 & 37.2 \\
\hline Pups & 0 & - & 0.64 & 0.30 & 0.6 & 2.2 & 27.6 \\
\hline Dispersers & 0 & - & 0.13 & - & 0.4 & 0.6 & 22.0 \\
\hline
\end{tabular}

played a role in a defensive encounter, particularly when two resident packs met, but the trespassing pack always retreated to their territory.

Changes in the rate of territory defense through the seasons was likely tied to defense of critical resources (i.e., mates, food, den sites) that may be in limited supply. Increased intrusions by lone animals and adjacent packs during winter may have been due to lower carcass biomass within their own area. Although aggregations of packs around an ungulate carcass suggests that some level of tolerance may be exercised around a large food source, defense by the resident pack still occurred (Gese et al. 1996a), which is similar to observations by Camenzind (1978). Bekoff and Wells (1986) also observed an increase in intrusions by nongroup coyotes during winter. Similarly, an increase in aggression during the breeding season due to elevated levels of reproductive hormones (Asa et al. 1990) could also explain the increased level of territory defense during breeding; or both factors (food and mates) may contribute to heightened defense during winter. The increase in defense during the pup season may be tied to den and pup defense. Camenzind (1978) reported that a litter of pups was killed at a den by a neighboring pack that had trespassed into the adjacent territory; 5 instances of den defense were also observed.

Physical contact involving ritualized behaviors or fighting (Schenkel 1947; Moran et al. 1981; Mech 1993) was observed when residents caught up to an intruder. In contrast to wolves (Van Ballenberghe and Erickson 1973; Mech 1994), no intruding coyotes were killed when the resident pack encountered them. Bekoff and Wells (1986) also observed no fatal encounters during territory defense. Okoniewski (1982) reported the rare occurrence of a fatal encounter between coyotes. The reason for this disparity, i.e., wolves killing intruders but coyotes not killing intruders, is still unknown.

All chases of intruders by resident animals ceased at or near the territory boundary. Upon arrival at the boundary, resident animals would initiate scent-marking and howling as the intruder retreated across the border. If the chase involved residents from adjacent packs, both packs would scent-mark and howl from their side of the border. Camenzind (1978) similarly observed that pursuit of an intruder ceased at the boundary and defenders would scent-mark at the boundary following a chase. Among wolves, fatal encounters were more prevalent along the edge; $91 \%$ of wolves killed by conspecifics were within $3.2 \mathrm{~km}$ of the territory boundary (Mech 1994).

Patterns of indirect mechanisms of defense (i.e., scent- marking and howling) followed similar trends to those observed for direct defense. Howling and scent-marking were generally performed by the alpha pair, while associate animals participated at lower rates and frequencies (Camenzind 1978; Wells and Bekoff 1981; Bekoff and Wells 1986; Gese and Ruff 1997, 1998). Scent-marking was more frequent during the breeding season and more frequently distributed along territory boundaries (Wells and Bekoff 1981; Bekoff and Wells 1986; Gese and Ruff 1997). Howling also followed similar seasonal trends and was usually performed by the alpha pair (Gese and Ruff 1998). However, as these and other observations illustrate, scent-marks and vocalizations do not keep intruders or neighboring packs out of a territory. Direct confrontation and enforcement of boundaries was still required to maintain the integrity of the territory (Mech 1994; Gese 1998). Peek (1972) proposed a three-tier system of defense in song birds. Song was used as a long-range warning signal to repel intruders at a distance, visual displays were used at an intermediate distance, and if the intruder persisted, then it was chased and attacked (Peek 1972). The rate at which coyotes perform these signals may indicate their relative importance and ability to deter intruders. For coyotes, howling (performed once per $4.8 \mathrm{~h}$ of observation; Gese and Ruff 1998) may serve as a long-distance warning, scent-marking (performed once per $1.2 \mathrm{~h}$ of observation; Gese and Ruff 1997) is the visual and olfactory signal used at shorter distances, and direct confrontation of the intruder (performed once per $22.4 \mathrm{~h}$ of observation) is used if the intruder ignores the other "keep out" signals.

Why resident pack members are territorial and therefore why they defend an area can best be explained by examining the advantages the residents received in terms of fitness (i.e., access to mates and food; Davies 1978). With regard to reproduction, territory holders were the only animals observed to acquire mating opportunities and successfully produce offspring. Equally importantly, alpha coyotes were the only animals to successfully rear their offspring to the age of independence, although most members of the resident pack did contribute to the care of the offspring (Hatier 1995). Inheritance of the alpha position should an alpha individual die, or be displaced from breeding status, occurred from within the resident pack (Gese et al. 1996c), although acceptance of the new alpha by the remaining alpha was not guaranteed and the alpha could recruit a new mate from outside the resident pack (Gese 1998). However, no transient or dispersing individuals were ever seen to be accepted into a pack and assume the alpha position. Perhaps the saturated coyote 
population in Yellowstone prevented or limited outside recruitment, and transient and dispersing animals may have a higher probability of acceptance or finding vacancies in areas or populations with lower survival rates. The increase in defense during the breeding season may be considered mate defense, but this period also coincides with the winter bottleneck for food resources and defense of carcasses (Camenzind 1978; Bekoff and Wells 1986; Gese et al. 1996a). The increase in defense during the time of pup emergence from the den may reduce the possibility of a neighboring resident pack killing the pups (Camenzind 1978).

Familiarity with the area and acquisition of a territory also influenced survival rates. Alpha and beta coyotes had high survival rates, while resident pups had low survival rates, mainly as a result of infectious diseases (Gese et al. 1997). Transients had similar survival rates to resident alpha and beta coyotes, likely because of the secure environment of the Lamar Valley (i.e., no human persecution). Dispersing animals had the lowest annual survival rates, as these individuals generally dispersed out of the park and were subject to human-caused mortality in unfamiliar areas. Similar differential survival rates among residents, transients, and dispersing individuals have been documented in other coyote populations (Tzilkowski 1980; Pyrah 1984; Andelt 1985; Bekoff and Wells 1986; Gese et al. 1989).

Defense of a territory by the alpha and beta coyotes provided them with increased access to ungulate carcasses during the winter bottleneck in availability of food resources. Residents, mainly the alpha pair, were the only animals to capture and kill adult ungulates during winter (Gese and Grothe 1995). The sociality of the pack may facilitate cooperative hunting of large ungulates during winter; transients and dispersing coyotes generally traveled alone and were not observed killing large prey, and they had little access to carcasses that were defended by the resident packs. Ready access to small mammals was also a benefit during all times of the year, although transients were equally capable of capturing small mammals. Thus, the evolution of defense of an area that increases fitness (Davies 1978) by encompassing food, mates, and den sites would be advantageous in coyote society (Brown and Orians 1970; Bekoff and Wells 1986). Territoriality allowed resident animals greater access to food, mates, and den sites, while lone transients and dispersing individuals had less opportunity for breeding and reduced access to ungulate carcasses. Defense of the area against other adjacent packs would be advantageous because an adequate food base, space, and mates would be guarded, thereby guaranteeing the integrity, reproductive effort, and survival of the pack throughout the year.

\section{Acknowledgements}

I thank Pat Terletzky, Ed Schauster, Alden Whittaker, Alexa Calio, Melissa Pangraze, Lara Sox, Levon Yengoyan, Danny Rozen, Scott Grothe, Kezha Hatier, Jeanne Johnson, John Roach, and Valeria Vergara for field assistance; John Cary and John Coleman for computer programming; and Robert Ruff for logistical and financial support during data collection. Data were collected while the author was a Ph.D. student in the Department of Wildlife Ecology at the University of Wisconsin-Madison. Funding and support were provided by the Department of Wildlife Ecology and the College of Agricultural and Life Sciences at the University of WisconsinMadison, National Park Service, Max McGraw Wildlife Foundation, U.S. Fish and Wildlife Service, National Geographic Society, Earthwatch, and the Hornocker Wildlife Research Institute.

\section{References}

Andelt, W.F. 1985. Behavioral ecology of coyotes in south Texas. Wildl. Monogr. No. 94.

Asa, C.S., Mech, L.D., Seal, U.S., and Plotka, E.D. 1990. The influence of social and endocrine factors on urine-marking by captive wolves (Canis lupus). Horm. Behav. 24: 497-509.

Bailey, T.N. 1993. The African leopard: ecology and behavior of a solitary felid. Columbia University Press, New York.

Balser, D.S. 1965. Tranquilizer tabs for capturing wild carnivores. J. Wildl. Manag. 29: 438-442.

Barrette, C., and Messier, F. 1980. Scent-marking in free-ranging coyotes, Canis latrans. Anim. Behav. 28: 814-819.

Bekoff, M., and Wells, M.C. 1986. Social ecology and behavior of coyotes. Adv. Study Behav. 16: 251-338.

Bowen, W.D. 1978. Social organization of the coyote in relation to prey size. Ph.D. dissertation, University of British Columbia, Vancouver.

Bowen, W.D., and Cowan, I.M. 1980. Scent marking in coyotes. Can. J. Zool. 58: 473-480.

Brown, J.L., and Orians, G.H. 1970. Spacing patterns in mobile animals. Annu. Rev. Ecol. Syst. 1: 239-262.

Burt, W.H. 1943. Territoriality and home range concepts as applied to mammals. J. Mammal. 24: 346-352.

Camenzind, F.J. 1978. Behavioral ecology of coyotes on the National Elk Refuge, Jackson, Wyoming. In Coyotes: biology, behavior, and management. Edited by M. Bekoff. Academic Press, New York. pp. 267-294.

Caro, T.M. 1994. Cheetahs of the Serengeti Plains: group living in an asocial species. University of Chicago Press, Chicago.

Cornely, J.E. 1979. Anesthesia of coyotes with ketamine hydrochloride and xylazine. J. Wildl. Manag. 43: 577-579.

Davies, N.B. 1978. Ecological questions about territorial behaviour. In Behavioural ecology: an evolutionary approach. Edited by J.R. Krebs and N.B. Davies. Blackwell Scientific Publications, Oxford.

Dirks, R.A., and Martner, B.E. 1982. The climate of Yellowstone and Grand Teton National Parks. Nat. Park Serv. Occas. Pap. No. 6.

Fritts, S.H., and Mech, L.D. 1981. Dynamics, movements, and feeding ecology of a newly protected wolf population in northwestern Minnesota. Wildl. Monogr. No. 80.

Fuller, T.K. 1989. Population dynamics of wolves in north-central Minnesota. Wildl. Monogr. No. 105.

Gese, E.M. 1998. Response of neighboring coyotes (Canis latrans) to social disruption in an adjacent pack. Can. J. Zool. 76: 19601963.

Gese, E.M., and Grothe, S. 1995. Analysis of coyote predation on deer and elk during winter in Yellowstone National Park, Wyoming. Am. Midl. Nat. 133: 36-43.

Gese, E.M., and Ruff, R.L. 1997. Scent-marking by coyotes, Canis latrans: the influence of social and ecological factors. Anim. Behav. 54: 1155-1166.

Gese, E.M., and Ruff, R.L. 1998. Howling by coyotes (Canis latrans): variation among social classes, seasons, and pack sizes. Can. J. Zool. 76: 1037-1043. 
Gese, E.M., Rongstad, O.J., and Mytton, W.R. 1988. Home range and habitat use of coyotes in southeastern Colorado. J. Wildl. Manag. 52: 640-646.

Gese, E.M., Rongstad, O.J., and Mytton, W.R. 1989. Population dynamics of coyotes in southeastern Colorado. J. Wildl. Manag. 53: $174-181$.

Gese, E.M., Ruff, R.L., and Crabtree, R.L. 1996a. Foraging ecology of coyotes (Canis latrans): the influence of extrinsic factors and a dominance hierarchy. Can. J. Zool. 74: 769-783.

Gese, E.M., Ruff, R.L., and Crabtree, R.L. 1996b. Intrinsic and extrinsic factors influencing coyote predation of small mammals in Yellowstone National Park. Can. J. Zool. 74: 784-797.

Gese, E.M., Ruff, R.L., and Crabtree, R.L. 1996c. Social and nutritional factors influencing the dispersal of resident coyotes. Anim. Behav. 52: 1025-1043.

Gese, E.M., Schultz, R.D., Johnson, M.R., Williams, E.S., Crabtree, R.L., and Ruff, R.L. 1997. Serological survey for diseases in free-ranging coyotes (Canis latrans) in Yellowstone National Park, Wyoming. J. Wildl. Dis. 33: 47-56.

Harrington, F.H. 1987. Aggressive howling in wolves. Anim. Behav. 35: 7-12.

Harrington, F.H., and Mech, L.D. 1978a. Howling at two Minnesota wolf pack summer homesites. Can. J. Zool. 56: 2024-2028.

Harrington, F.H., and Mech, L.D. 1978b. Wolf vocalization. In Wolf and man: evolution in parallel. Edited by R.L. Hall and H.S. Sharp. Academic Press, New York. pp. 109-132.

Harrington, F.H., and Mech, L.D. 1979. Wolf howling and its role in territory maintenance. Behaviour, 68: 207-249.

Harrington, F.H., and Mech, L.D. 1983. Wolf pack spacing: howling as a territory-independent spacing mechanism in a territorial population. Behav. Ecol. Sociobiol. 12: 161-168.

Hatier, K.G. 1995. Effects of helping behaviors on coyote packs in Yellowstone National Park, Wyoming. M.S. thesis, Montana State University, Bozeman.

Heisey, D.M., and Fuller, T.K. 1985. Evaluation of survival and cause-specific mortality rates using telemetry data. J. Wildl. Manag. 49: 668-674.

Houston, D.B. 1982. The northern Yellowstone elk: ecology and management. Macmillan Publishing Co., Inc., New York.

Lehner, P.N. 1979. Handbook of ethological methods. Garland STPM Press, New York.

Linhart, S.B., and Knowlton, F.F. 1967. Determining age of coyotes by tooth cementum layers. J. Wildl. Manag. 31: 362-365.

Martin, P., and Bateson, P. 1993. Measuring behavior: an introductory guide. 2nd ed. Cambridge University Press, London.

Mech, L.D. 1966. The wolves of Isle Royale. Natl. Park Serv. Fauna Ser. No. 7.
Mech, L.D. 1970. The wolf: the ecology and behavior of an endangered species. Natural History Press, Garden City, N.Y.

Mech, L.D. 1973. Wolf numbers in the Superior National Forest of Minnesota. U.S. For. Serv. Res. Pap. NC-97.

Mech, L.D. 1993. Details of a confrontation between two wild wolves. Can. J. Zool. 71: 1900-1903.

Mech, L.D. 1994. Buffer zones of territories of gray wolves as regions of intraspecific strife. J. Mammal. 75: 199-202.

Moran, G., Fentress, J.C., and Golani, I. 1981. A description of relational patterns of movement during 'ritualized fighting' in wolves. Anim. Behav. 29: 1146-1165.

Murie, A. 1944. The wolves of Mount McKinley. Natl. Park Serv. Fauna Ser. No. 5.

Okoniewski, J.C. 1982. A fatal encounter between an adult coyote and three conspecifics. J. Mammal. 63: 680-682.

Peek, F.W. 1972. An experimental study of the territorial function of vocal and visual display in the male red-winged blackbird (Agelaius phoeniceus). Anim. Behav. 20: 112-118.

Peters, R.P., and Mech, L.D. 1975. Scent-marking in wolves. Am. Sci. 63: 628-637.

Peterson, R.O. 1977. Wolf ecology and prey relationships on Isle Royale. Natl. Park Serv. Sci. Monogr. Ser. No. 11.

Pyrah, D. 1984. Social distribution and population estimates of coyotes in north-central Montana. J. Wildl. Manag. 48: 679690.

Rabb, G.B., Woolpy, J.H., and Ginsberg, B.E. 1967. Social relationships in a group of captive wolves. Am. Zool. 7: 305-311.

Rothman, R.J., and Mech, L.D. 1979. Scent-marking in lone wolves and newly formed pairs. Anim. Behav. 27: 750-760.

Schenkel, R. 1947. Expression studies of wolves. Behaviour, 1: 81-129.

Schenkel, R. 1967. Submission: its features and function in the wolf and dog. Am. Zool. 7: 319-329.

Sokal, R.R., and Rohlf, F.J. 1981. Biometry. W.H. Freeman and Co., New York.

Trent, T.T., and Rongstad, O.J. 1974. Home range and survival of cottontail rabbits in southwestern Wisconsin. J. Wildl. Manag. 38: 459-472.

Tzilkowski, W.M. 1980. Mortality patterns of radio-marked coyotes in Jackson Hole, Wyoming. Ph.D. thesis, University of Massachusetts, Amherst.

Van Ballenberghe, V., and Erickson, A.W. 1973. A wolf pack kills another wolf. Am. Midl. Nat. 90: 490-493.

Wells, M.C., and Bekoff, M. 1981. An observational study of scentmarking in coyotes, Canis latrans. Anim. Behav. 29: 332-350.

Zar, J.H. 1996. Biostatistical analysis. 3rd ed. Prentice Hall Inc., Upper Saddle River, N.J. 
Copyright $\odot 2003$ EBSCO Publishing 